\title{
The Impact of eCRM on Loyalty and Retention of Customers in Iranian Telecommunication Sector
}

\author{
Alireza Abdolhosseini Khaligh (Corresponding author) \\ MBA Graduated from Sharif University of Technology-International Campus \\ Tabriz, Iran \\ E-mail: arkhaligh@alum.sharif.edu, arkhalig@yahoo
}

Alireza Miremadi

School of Management, Sharif University of Technology-International Campus

Amir Kabir Square, Kish Island, Iran

Tel: 98-913-315-2401

E-mail: ar.miremadi@sharif.edu, alireza.miremadi@gmail.com

Mansoor Aminilari

Islamic Azad University of Shiraz, Research and Science Unit

Apt. Hayat, $4^{\text {th }}$ Street, Abrishami Avenue, Gas Square, Shiraz, Iran

Tel: 98-917-714-6132Ｅ-mail: shirazu1381em@yahoo.com

Received: July 25, 2011

Accepted: September 5, $2011 \quad$ Published: January 16, 2012

doi:10.5539/ijbm.v7n2p150

URL: http://dx.doi.org/10.5539/ijbm.v7n2p150

\begin{abstract}
The research approach is to appraise the impact of electronic customer relationship management in creating loyalty and retention of customers in Iran mobile telecommunication sector. 200 customers who use Iranian mobile telecom operators' services (Hamrah-e Avval, Irancell, and Taliya) have been asked as respondents in this research. The objective of this study is to find the relationship between eCRM effective factors and loyalty and retention factors in order to conduct the Iranian mobile telecom operators to be successful in enhancing loyalty and retention of their customers in this field. With this Approach, the results of our research shows which factors are effective and which factors are not in Iranian mobile telecom sector. This study enables the manager of this sector to implement the eCRM in the best shape and match it with Iranian culture to create more loyalty and retention.
\end{abstract}

Keywords: eCRM, Loyalty, Retention, Telecommunication, Iran

\section{Introduction}

The new technologies have played a crucial role in the human life in duration of two recent decades and have highly changed the lifestyle. Nowadays, Mobile phone is the phenomenon which has overshadowed the human life.

Under such circumstances, and to take steps forward in harmony with the global developments, mobile telecom system was launched for the first time in Iran in 1994 by establishment of network with capacity of 9200 cell phone. Considering the community needs and the demands of the customers, in harmony with the global community, the state telecommunication industry has taken valuable steps forward towards development of mobile telecom network.("Hamrahe Avval ( First Operator ) - History,")

The exploitation of mobile telecom system was started for the first time in Iran in 1994 by use of 176 transmitters and receiver installed in 24 stations and with 9200 cell phone numbers. The high demand of the subscribers of this phenomena caused ITC to extend the coverage and facilities and, by March 2006, the number 
of cell phone customers increased to 15907 and, in addition to Tehran, some big cities such as Mashhad, Ahwaz, Tabriz, Isfahan and Shiraz were covered. ("Hamrahe Avval ( First Operator ) - History,")

In according to operators' website information, the growing trend of the system continued in the following years and, in addition to the above-named cities, the coverage provided for a number of 28 new cities. The number of subscribers had been increased from 59,967 in 1994 to 3,449,878 in March 2004. In line with this extension trend and following the policies of the government regarding provision of enjoyment for all classes of the community, including those living in small cities like large cities, the number of cities under network coverage increased from 134 in March 1997 to 667 cities in March 2004. ("Hamrahe Avval ( First Operator ) - History,")

Presently, the number of mobile telephone network subscribers has increased to more than 44 million more than 1148 cities and the coverage has been provided for more than $52,000 \mathrm{~km}$ road network throughout the country. The penetration coefficient of the subscribers is about $59 \%$ of the community and roaming services have been provided in more than 110 countries. ("Hamrahe Avval ( First Operator ) - History,")

Iran has 3 main mobile phone telecom network operators which provide mobile telecom services for Iranian customers. Theses operators are Hamrah-e Avval, Irancell and Taliya.

Hamrah-e Avval is the first Iranian mobile telecom network operator which has provided the coverage 1148 cities of Iran. In year 2004, the number of the subscribers of Hamrah-e-Avval grew up to 3,450,000 subscribers; the number of subscribers of this operator is more than 44 million today. ("Taliya - Wikipedia, the free encyclopedia,"), ("Taliya,")

Irancell is the second mobile telecom network operator of Iran. It is $49 \%$ owned by the South Africa-based MTN Group. MTN Irancell is the first network operator of Iran which provides GPRS and MMS service and will let subscribers choose their desired number in a specific range of digits. Irancell is a private joint stock company governed by the Commercial Code of the Islamic Republic of Iran as amended in the year 1969 and the provisions of its Articles of Association. The Company was registered in 2005. The Company has been established for an indefinite period of time. From January 2010, Irancell began their WiMAX internet services in major cities of Tehran, Shiraz, Isfahan, Tabriz, Mashhad, Karaj and Ahvaz. ("MTN Irancell - Wikipedia, the free encyclopedia,")

Taliya is the third largest mobile phone network operator in Iran. It was the first Independent and private prepaid mobile network in Iran which has started in 2004 using state of the art technologies from Siemens. In the first phase of the operation, it was activated in Tehran and according to the next phases of program, it has been activated in other big cities of Iran like Mashhad, Isfahan, Tabriz, Shiraz, Qom, Ahvaz, and so on.

The purpose of this study is to evaluate the impact of electronic customer relationship management in creating loyalty and retention of customers in Iranian telecommunication sector by focusing on mobile phone telecom sector. This research will start with a background of the research subject which will be a study within the field of electronic customer relationship management and its influences on customer loyalty and retention. In this study we attempt to discuss about the main factors of every dependent and independent variables of research. This research is continued by factors analysis to extract fundamental factors which are important as customer's point of view to analyze the relationship of every factor in the analytical model which can be operational solution for Iranian mobile telecommunication operators in eCRM use for attracting and retaining customers in mobile telecom sector. In order to achieve this purpose, the research focuses on analyzing the developed conceptual model from consumer's perspective.

\section{Literature Review}

\subsection{Marketing}

Marketing is one of the central parts of successful management today which impacts on society through different styles; it helps organizations know what people want and need; helps people find products and services that meet their needs; conveys information that makes people's lives more efficient and effectual; creates exchanges that develop employment and wealth. Marketing influences on the environment and the communities in which we live. "In relationship with marketing, Kotler (2001) mentioned that the core concept of marketing is wants and demand, products and services, value, satisfaction, quality, exchange, transactions, relationship, markets." (Kotler, et al., 2001)

\subsection{Relationship Marketing}

Relationship marketing is attracting, maintaining, and enhancing customer relationships which can be applied when there are competitive product alternatives for customers to choose from and when there is an ongoing and repeated request for the product or services. In service industry such as telecommunication sector these strategies play a vital role in enhancing retention. Consolidating customer relationships and transforming them into loyalty 
and serving customers as clients should be a part of marketing (Berry, 1983).

Succeeding subject on relationship marketing expands profitability of relationship management. "Companies build profitable and long term relationship with applying customer relationship management (Kotler \& Armstrong, 2005).

Relationship marketing has come into existence as a leading strategic element of business in recent past years. It has a direct effect on firm's objective performance and also proposes that the effectiveness of relationship marketing is high when the relationships are more important to customers (Robert \& Daunt, 2006).

Relationship marketing in telecommunication service industry plays significant role because of unique characteristics in this sector. It is an approved issue that frequency in act of buying generators value in the service industries such as telecommunication sector (Berry, 1995).

\subsection{CRM and eCRM}

CRM is a strategy for companies to build and manage long-term relationships with their customers (Blery \& Michalakopoulos, 2006). Researchers have shown that CRM implementation can provide better customer service, as well as improvement and management of customer expectations and loyalty (Cho, Im, Hiltz, \& Fjermestad, 2001; F. Reichheld, 1996; F. F. Reichheld \& Sasser, 1990; Romano, 2001; Winer, 2001). CRM also complements a firm's capability to present products, quality, and services to its customers (Chen \& Sukpani, 1998). By implementing CRM solutions, many firms expect to improve profitability by gaining customer loyalty, customizing offerings, and lowering costs. The increasing pressure on profitability has motivated companies across different industry sectors to invest in CRM solutions (Chan \& Lam, 2009).

Internet technology has transformed CRM into electronic CRM (eCRM), because companies can use Internet technologies to capture new customers, track their preferences and online behaviors, and customize support and services (Chan \& Lam, 2009).

"Electronic Customer Relationship Management" is a tool to maintain its customer relations by using the Internet and what benefits are derived by using this eCRM tool and how successfully this tool is implemented in one industry (Ab Hamid, 2005).

Kennedy says that eCRM (electronic Customer Relationship Management) is considered as strategic technology centric relationship marketing business framework. According to Forrester's Research (2001), eCRM is the consolidation of traditional CRM with e-business market place applications.

While Shan and Lee (2003) say that "eCRM expands that traditional CRM techniques by integrating of new electronic channels, such as Web, wireless and voice technologies, and combines them with e-business applications into the overall enterprise CRM strategy". They further say "the ability to capture, integrate and distribute data gained at the organization's Web site throughout the enterprise."

According to Adebanjo (2003) selection of eCRM for one organization requires combinations of factors which should be managed properly. It reduces the cost of communication with customers and help to enhance customer interaction, personalization and relationship opportunities.

The purpose of eCRM is to serve the customers in better way, retain valuable customers and enhance analytical capabilities in an organization (Fjermestad \& Romano, 2003).

\subsection{Loyalty and Retention}

Studies often report that, on average, it costs a company more to attract a new customer as it does to implement a retention strategy (Kelley, Gilbert, \& Mannicom, 2003). Reichheld and Sasser (1990) in their study of the Internet clothing market found that customer acquisition cost is 20 per cent to 40 per cent greater than acquiring a new customer in the traditional retailing marketplace. This leads to higher losses in the early stages of the relationship, but in months 24 to 30, the Internet customers are likely to spend twice as much as they did in the first six months (F. F. Reichheld \& Schefter, 2000). In an earlier study, Reichheld and Sasser found that existing customers are not only less price sensitive; they are more economical to maintain than new customers. Yin and Kannan (1999) defines "hard-core" loyalty as consisting exclusively of repeat purchase behavior. At the same time, Bentley's study (1999) has linked customer loyalty directly to profitability by confirming Reichheld and Sasser's (1990) suggestion that loyal customers are less sensitive to price changes and are more susceptible to being charged premium prices. Gilbert (1996) postulates that relationship management (RM) schemes can reduce the long-term costs of attracting new customers by increasing the length of time they would stay with a company.

As a general rule, customer Retention and customer loyalty are very closely related. Customer Retention functions as an antecedent of customer loyalty. It prevents customer churn and consolidates retention, thereby 
constituting an important cause of customer loyalty (Fornell, 1992; F. Reichheld, 1996).

Thus, e-CRM refers to the marketing activities, tools and techniques, delivered over the Internet (using technologies such as Web sites and e-mail, data-capture, warehousing and mining) with a specific aim to locate, build and improve long-term customer relationships to enhance their individual potential.

\subsection{Telecommunication}

Telecommunications enhance national productivity by reducing transaction costs, improving marketing information, and accelerating the diffusion of knowledge (Antonelli, 1991; Greenstein \& Spiller, 1995). In an emerging global economy, characterized by greater trade liberalization and increasing information needs, telecommunications provide a basis for competitive advantage. The ancient provision of telecommunications services facilitates the ordering, payment and delivery of traded goods and services, whilst electronic commerce promises to make trade less expensive, easier to transact, and more extensive in geographical scope. Further, as new technology and applications become available when there is potential to open up new information-based service markets (Madden \& Savage, 1999).

Furthermore, the convergence of telecommunication provides companies with opportunities to interact with their customers through a new channel.

\section{Hypotheses and Research Frame Work}

\subsection{Hypotheses}

This study has been undertaken with the following specific objectives:

H1) There is an association between Applicability of e-CRM and loyalty of customers in telecommunication industry.

H2) There is an association between Applicability of e-CRM and retention of customers in telecommunication industry.

\subsection{Theoretical works}

Theoretical section contains theories and models about the research variables used in this study, the theory of the relationship marketing will be discussed firstly, and then followed by discussing about the customer relationship management, electronic customer relationship management, customer loyalty, customer retention, in which each construct showed in the model is discussed respectively, and the factors are extracted from models which can be efficient and presumable for this study, and the research hypothesizes can be studied accordingly.

\subsection{Conceptual frame work}

In this research, we have started a deep study on relevant articles to find models related to my thesis to collect the appropriate attributes with the variables that we've used to define the new topic for the thesis. So, at first look it was hard job and we studied a lot of papers, articles to know and grasp the meaning of analytical models and related structures used in the articles methodology section. After a two month preliminary Study, We could excerpt essential articles as a noticeable and drastic references to start our research on verifying the attributes and setting them as the starting point. The project was only in the initial phase as yet.

After this stage, we entered a new phase in the research. We selected the effective models and attempted to match their factors with this thesis. After half a month, the loyalty, retention and eCRM factors were ready as raw factors to design the thesis questionnaire.

The questions of each variable were written independently with regard to their factors and sub factors.

\section{Research Methodology}

The purpose of this study is to discover and analyze the impact of loyalty and retention for customer as driving factors in mobile telecom sector in Iran and measure their eCRM effectiveness on them, and finally compare their impact on three famous mobile telecom service providers (Hamrah-e Avval, Irancell, Taliya) in Iranian mobile telecommunication sector: Initially, an exploratory pilot testing was conducted on 60 mobile respondents to identify the factors which would be considered and used in structuring the final questionnaire and the respondents were from diverse backgrounds. The study was conducted in the main cities of Iran. The questionnaire finally consisted of fifty and two statements as vital factors and the mobile user respondents were asked to indicate the level of agreement with these on a five point scale ( $1=$ strongly disagree, $7=$ strongly agree). It was administrated to two hundreds mobile user respondents.

\subsection{Research Approach and Measurement}

Measurement is described as assigning number to a variable base on certain rules. This apportion must express the attributes of the phenomenon being evaluated (Hair, Money, Samouel, \& Page, 2007). The used 
questionnaire is divided to two parts. In section one, individuals were asked to give some descriptive information about themselves such as, education, gender, job positioning, experience and their intention to repurchase from existing service provider. In section two, a set of questions is designed to evaluate variables represented in hypotheses. In this section, all the questions use seven point Likert scale responses. A scale is one of the measurement tools which can be used to assess a question with a preordained number of the results (Hair, et al., 2007).

The research approach is to come nearer to research hypotheses and respond to research questions. It means that the research wants to find the relationship between eCRM effective factors and Loyalty and retention factors in order to conduct the Iranian mobile telecom operators to be successful in enhancing loyalty and retention of their customers in this field.

With this Approach, after pilot test, the first results will show which factors are effective and which factors are not. After getting the first results, we will pay attention to the SPSS statistical outcome and specify the research path.

\subsection{Factors of eCRM which effect on Loyalty and Retention of Customers}

In this research we face with complexity of components. We have extracted components from different models and articles and join them to setup the base of our research. At the end, we start the analysis with 49 components. As we mentioned, the components are divided by 3 main groups. The first group of components has 12 components which pertain to Customer Loyalty. The second group of components has 27 components which pertain to Customer Retention. The last group of components is the eCRM components which has 10 components (Table-1).

\subsection{Data collection}

We have conducted face-to-face interviews with participants of this research in April 2011, at first with 60 useable responses from 71questionnaires were distributed among different social classes with various job, age, education and income to coordinate the pilot test of our research covering different ideas from Iranian society. Then our research main tests were conducted with 200 useable responses from 218 respondents through Internet Online Survey in duration of 55 days in May and June 2011. Respondents' gender, age, Educational Level, job profiles have been illustrated in Table-2 in May 2011. Attitudes on each of the independent variables has been evaluated using five-point Likert scales attached firmly by the agreement level of each question with point of $1=$ strongly disagree and $7=$ strongly agree. Dependent variables have been appraised by level of acceptability with point of $1=$ totally unacceptable and $7=$ perfectly acceptable.

\subsection{Data Analysis}

\subsubsection{Evaluating Measurement Scale}

Before devoting score to any construct or factor for analysis, researchers should consider that whether chosen variables to represent and measure are accurate or in consistent manner. According to Hair et al. (2007) consistency is related to the term reliability however, accuracy is related to the term validity.

Hair et al. (2007) argues that reliable questionnaire should produce the same results if repeated. Participants should answer the questions in consistency manner. In addition to test-retest reliability and alternative forms reliability, internal consistency is used to evaluate summated scale. Internal consistency includes two types: first split-half reliability and second coefficient alpha referred to Cronboch's alpha. When the range of Cronbach's alpha is from 0.35 to 0.7 , the reliability of the questionnaire is medium. When it is higher than 0.7 , the reliability of the questionnaire is considered high. Calculated Cronboch's alpha in this research by SPSS 18 has been represented in table 3.

\subsubsection{Reliability of Main Factors and Internal Factors of Retention}

A reliability test, based on Cronbach's Alpha, is used to test the each internal consistency of each construct (factor) and the result shows all of 3 factors have internal consistency. Customer Loyalty, Customer Retention, and electronic Customer Relationship (eCRM) have $\alpha$ values higher than 0.7 so their consistency is high (Cronbach, 1951; Nova'k, Christine, \& Abetz, 2004; Ware, Kosinski, \& Gandek, 1998), (Table-3).

Customer Retention has 27 variables which have been extracted from models that other researchers have proposed in previous researches. Clustering these variables cause 6 constructs (internal factors) to be generated. These 7 constructs are Customer Satisfaction, Customer Involvement, Trust, Attraction of alternatives, Service Quality, Price, and Switching Barrier. Cronbach's Alpha is used to test the internal consistency of each construct (factor) and the result shows 4 factors of Customer Involvement, Service Quality, Price, and Switching Barrier have the $\alpha$ values higher than 0.7 so their consistency is high, but the Cronbach's Alpha of Customer Satisfaction, Trust, and Attraction of alternatives are between 0.4 and 0.7 which shows normal consistency (Cronbach, 1951; 
Nova'k, et al., 2004; Ware, et al., 1998), (Figure 1).

\subsection{Structured Model and Multiple Regression}

Multiple regression analysis used in this study can be the most widely applied data analysis approach to assess the linear relationship among two or more variables. In this research, the relationship is measured between as eCRM dependent variable and other Customer Loyalty (CL) and Customer Retention (Cronbach) as independents variable in Iran mobile telecom section.

The correlation analysis shows a relationship between two existent variables and also the overall strength of the relationship. But it does not prepare enough information for managers to make appropriate decisions. But regression analysis examines the relationship between several variables as whole. In multiple regression different independent variables are entered into the same kind of regression equation and then the single dependent variable is assessed. For each independent variable a segregate regression coefficient is calculated. This regression coefficient indicates the relationship between each individual independent variable and dependent variable. In addition, researcher can assess the amount of the different independent variables effect on dependent variable. The relationship between dependent and each independent variable is supposed to be linear. In multiple regression, the regression and beta coefficient for each independent variable explain the average amount of change in dependent variable $(\mathrm{Y})$ and also a unit change in independent variable $(\mathrm{X})$ while the range of beta coefficient is between -1 to +1 . It can also make a comparison among independent variables to calculate the amount of effect that they have on dependent variable (Hair, et al., 2007). The greater amount of beta coefficient is more important to predict dependent variable. According to the (Hair, et al., 2007), the concept of multi coefficient of determination denoted by $\mathrm{R}$ square is used to assess the capability of the multiple independent variables to predict a single dependent variable and it can show the amount of the variation in dependent variable described by the different independent variable in the model. A greater amount of $\mathrm{R}$ square shows the stronger relationship available between dependent variable and multiple independent variables. (Hair, et al., 2007) argue that the overall regression model is seen when it is statistically significant. The probability of statistical significance must be less than 0.05 . However some business researchers accept a lower level of probability less than 0.1 . On the other hand, some of the other researchers discuss that it should be less than 0.01 . Testing statistical significant of the beta coefficient is the key important issue in multiple regression for each of independent variable. If any of them is not statistically significant for that particular factor, it means that it is not appropriate predictor for dependent variable. So any insignificant beta coefficient of independent variable is meaningless and should be removed.

Insert Figure 1 here

\subsection{Model statistical Analysis}

The statistical analysis process mentioned above is done by researcher with SPSS 18 . The researcher calculates multiple regressions by stepwise method. In this approach, statistical significant of the overall model with $\mathrm{F}$ statistic is evaluated, if $\mathrm{F}$ was significant (if probability of $\mathrm{F}$ is lower than 0.05 , factor is entered otherwise the factor will be removed). This process was done through some steps. In each step a model develops with separated R square and also calculated each of the beta coefficients and their t-value to identify which factor has statistically significant coefficients and continued the process with recalculating the regression with the significant independent variable.

In this study, as it is illustrated in the following tables through this process 2 models are extracted. With added independent variables in each multiple regression model, its $\mathrm{R}$ square is increased. In this study, to prevent overestimating the effect of adding an independent variable to the model, Adjusted R square is used.

According to the information provided in ANOVA table (6), all regression models are statistically significant $($ F-ratio of models $=154.913,98.363)$ and with the probability level $=0.000)$. The 0.000 probability level indicates that the likelihoods are 0.000 for the regression models. That's why they have random events instead of an appropriate relationship. As it is illustrated in coefficients tables of regression models, it indicates that whether independent variables do predict repurchase intention as dependent variable significantly does. As mentioned before, greater amount of beta coefficient is more important to predict dependent variable. In addition, Student's t-distribution is a probability used especially in testing hypotheses with regarding means of normal distributions whose standard deviations is generally not known and that is the distribution of a random variable (Merriam-Webster, 2005). In confidence level of 0.975, the $t$-student must be larger than 1.95996. All $t$-values illustrated in following tables are met with this amount.

In this study, as it is illustrated in following tables, through this process 5 models are extracted and it is also shown that with added independent variables in each multiple regression model, its $\mathrm{R}$ square is increased. In this study, to prevent overestimating the effect of adding an independent variable to the model, Adjusted R square is 
used.

According to the information provided in ANOVA table (9), all regression models are statistically significant (F-ratio of models $=115.708,70.374,52.705,41.769,35.694)$ and with the probability level $=0.000)$. The 0.000 probability level indicates that the likelihoods are 0.000 which the regression models are because of random events instead of an appropriate relationship.

As illustrated in coefficients tables of regression models indicate that whether independent variables do predict repurchase intention as dependent variable significantly. As mentioned before, greater amount of beta coefficient has more importance to predict dependent variable. In addition, t-student is a probability used especially in testing hypotheses with regarding means of normal distributions and its standard deviation is generally not known and that is the distribution of a random variable (Merriam-Webster, 2005). In confidence level of 0.975, the t-student must be larger than 1.95996. All $\mathrm{t}$-values illustrated in the following tables are met with this amount.

\section{Conclusion \& Recommendation}

In today's very competitive and constantly changing telecommunications market, the Iranian mobile telecommunication service operators consider the implementation of customer loyalty and customer retention as very important issues and attempt to expand the eCRM. However, eCRM significantly can help the information flow within the Organization as well as improve its relationships with customers. All users have positive comments from the use of eCRM in mobile telecom sector which should be considered as a point of success for Iranian mobile telecom operators.

Nevertheless, according to the findings, for the successful implementation of the system, vision and commitment from the management are needed. Strategic priority should be given to tangibility; scalability and flexibility that are important factors to construct the customer loyalty in Iranian mobile telecom industry whereas for implementing the customer retention consideration, the priority should be given to personal compatibility, professional competence, frontline employees, quality of services and pricing policies attractions. These findings can become useful marketing tools for the managers of the telecommunication organizations in Iran and other countries.

\subsection{Research Limitation}

One of the limitations of this study is that in Iran the number of mobile phone telecom network operators is limited and these networks are under the monopoly of three big operators. Since Hamrah-e Avval is the first operator of Iran which has the largest amount of customers with postpaid SIM while two other operators Irancell and Taliya - mostly have the customers with prepaid SIM so the customers have fewer alternatives to choose. This issue causes customers to be optimistic in duration of answering questions. Consequently, under these circumstances, it is difficult to compare the performance of the Iranian mobile phone telecom operators. Finally, it should be considered that all the results of this study are affected by mentioned conditions.

\section{References}

Ab Hamid, N. R. (2005). E-CRM: are we there yet? Journal of American Academy of Business, 6(1), 51-57.

Adebanjo, D. (2003). Classifying and Selecting e-CRM Applications: An Analysis-Based Proposal. Management Decision, 41(6), 570-577. http://dx.doi.org/10.1108/00251740310491517

Antonelli, C. (1991). The diffusion of advanced telecommunications in developing countries. Research Policy, 23(3), 253-254. http://dx.doi.org/10.1016/0048-7333(94)90046-9

Bentley, A. (1999). Sales through service. International Journal of Customer Relationship Management, 1(4), 337-334.

Berry, L. (1983). Relationship Marketing. Paper presented at the Proceedings of Services Marketing Conference, Chicago.

Berry, L. (1995). Relationship Marketing of Services - Growing Interest, Emerging Perspectives. Journal of the Academy of Marketing Science, 23(4), 236-245.

Blery, E. K., \& Michalakopoulos, M. G. (2006). An e-CRM application in the telecommunications sector: A case study from Greece. EuroMed Journal of Business, 1(2), 5-14. http://dx.doi.org/10.1108/14502190610750135

Chan, S., \& Lam, J. (2009). Customer Relationship Management on Internet and Mobile Channels: An Analytical Framework and Research Directions. Idea Group Inc.

Chen, L., \& Sukpani, N. (1998). Assessing consumers' involvement in Internet purchasing. The International Journal of Organizational Innovation, 1(2).

Cho, Y., Im, I., Hiltz, S. R., \& Fjermestad, J. (2001). Causes and outcomes of online customer complaining 
behavior: Implications for customer relationship management (CRM). Paper presented at the Proceedings of the Seventh Americas Conference in Information Systems (AMCIS), Boston.

Cronbach, L. (1951). Coefficient alpha and the internal structure of tests. Psychometrika, 16, $297-334$. http://dx.doi.org/10.1007/BF02310555

Fjermestad, J., \& Romano, N. C. (2003). Electronic customer relationship management: revisiting the general principles of usability and resistance: an integrative implementation framework. Business Process Management Journal, 9(5), 572-591. http://dx.doi.org/10.1108/14637150310496695

Fornell, C. (1992). A national customer Retention barometer: The Swedish experience. Journal of Marketing, $56(1), 6-21$.

Forrester. (2001). [Online] Available: http://www.forrester.com

Gilbert, D. C. (1996). Relationship marketing and airline loyalty schemes. Tourism Management, 17(8), 575-582. http://dx.doi.org/10.1016/S0261-5177(96)00078-7

Greenstein, S. M., \& Spiller, P. T. (1995). Modern telecommunications infrastructure and economic activity: An empirical investigation. Industrial and Corporate Change, 4(4), 647-665. http://dx.doi.org/10.1093/icc/4.4.647

Hair, J. F., Money, A. H., Samouel, P., \& Page, M. (2007). Research methods for business. England: John Wiley and Sons, Inc.

Hamrahe Avval (First Operator ) - History. (August 31, 2011). [Online] Available: http://mci.ir/web/en/home

Kelley, L. L., Gilbert, D., \& Mannicom, R. (2003). How e-CRM Can Enhance Customer Loyalty. Marketing Intelligence and Planning, 21(4), 239-248. http://dx.doi.org/10.1108/02634500310480121

Kennedy, A. (2006). Electronic Customer Relationship Management (eCRM): Opportunities and Challenges in a Digital World. Irish Marketing Review, 18(1\&2), 58-69.

Kotler, P., \& Armstrong, G. (2005). Principles of Marketing. New Delhi, India: Prentice Hall.

Kotler, P., Armstrong, G., Saunders, J., \& Wong, V. (2001). Principles of Marketing (3rd European Edition ed.): Financial Times Prentice Hall.

Madden, G., \& Savage, S. J. (1999). Telecommunications productivity, catch-up and innovation. Telecommunications Policy, 23(1), 65-81. http://dx.doi.org/10.1016/S0308-5961(98)00076-7

Merriam-Webster. (Ed.) (2005). Incorporated.

MTN Irancell - Wikipedia, the free encyclopedia. (August 31, 2011). [Online] Available: http://en.wikipedia.org/wiki/MTN_Irancell

Nova'k, A., Christine, L., \& Abetz, L. (2004). Development and validation of an acceptability and satisfaction questionnaire for a contraceptive vaginal ring. Pharmaco Economics, 22(4), 245-256.

Reichheld, F. (1996). The loyalty effect: The hidden force behind growth, profits, and lasting value. Boston: Bain and Company, Inc. Harvard Business School Press.

Reichheld, F. F., \& Sasser, W. E. J. (1990, September-October). Zero defects comes to services. Harvard Business Review, 105-111.

Reichheld, F. F., \& Schefter, P. (2000, July-August). E-loyalty: your secret weapon on the Web. Harvard Business Review, 105-113.

Robert, W. P., \& Daunt, R. P. (2006). Factors Influencing the Effectiveness of Relationship Marketing. Journal of Marketing, 70(4), 136-153. http://dx.doi.org/10.1509/jmkg.70.4.136

Romano, N. J. (2001). An agenda for electronic commerce customer relationship management research. Paper presented at the Proceedings of the Seventh Americas Conference in Information Systems, Boston, MA.

Shan, L. P., \& Lee, J. (2003). Using e-CRM for a Unified View of the Customer. Communications of the ACM, 46.

Taliya - Wikipedia, the free encyclopedia. (August 31, 2011). [Online] Available: http://en.wikipedia.org/wiki/Taliya

Taliya. (August 31, 2011). [Online] Available: http://www.taliya.ir/

Ware, J., Kosinski, M., \& Gandek, D. (1998). The factor structure of the health survey in 10 countries. International Quality of Life Assessment, 51, 159-165.

Winer, R. S. (2001). Relationship Management: A Framework, Research Directions, and the Future.

Yin, C. K., \& Kannan, P. K. (1999). Consumer behaviour loyalty: a segmentation model and analysis. Journal of 
Business Research, 44(2), 75-92. http://dx.doi.org/10.1016/S0148-2963(97)00243-9

Table 1. Components of Loyalty, Retention and eCRM

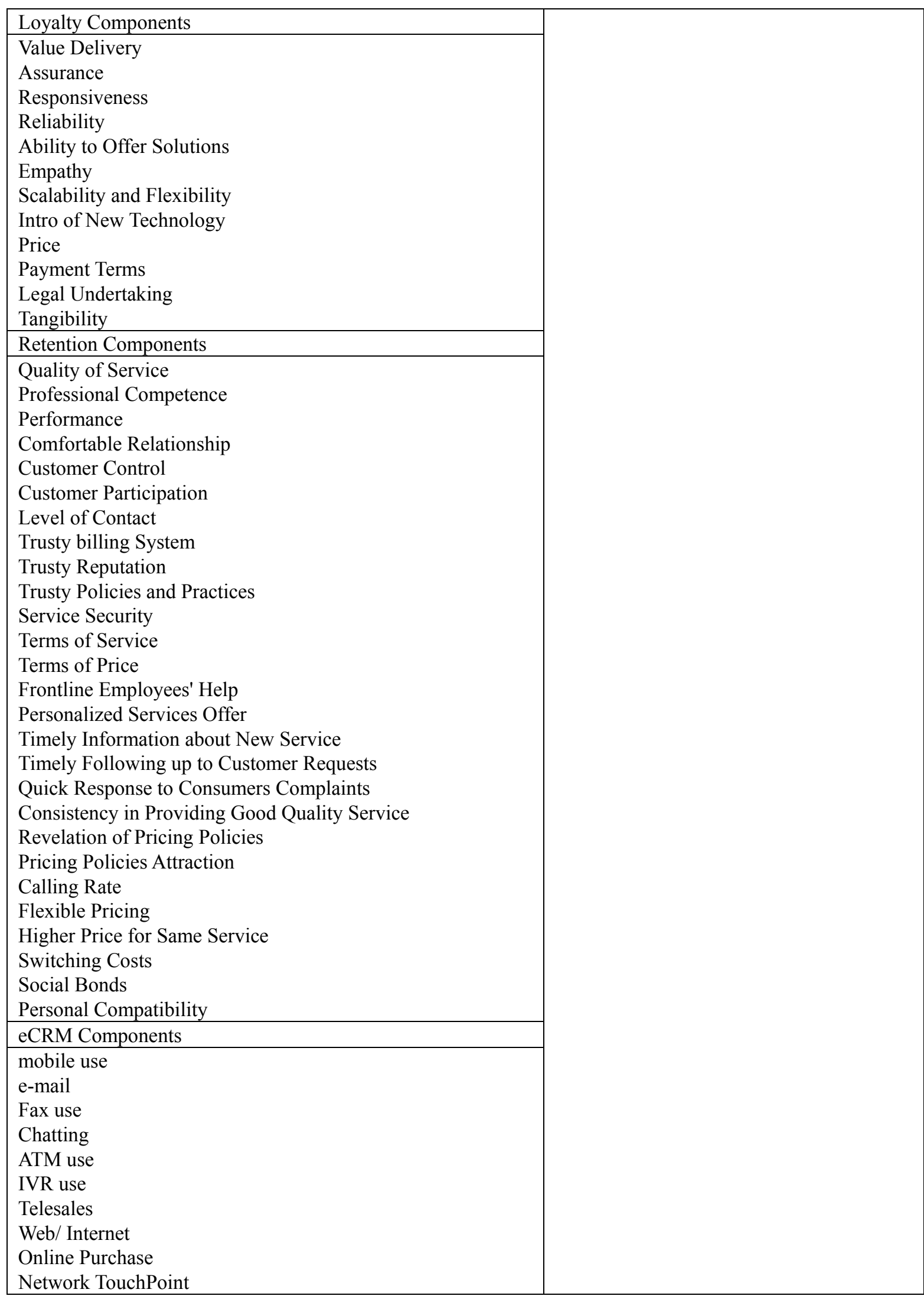


Table 2. Respondents' Profiles

\begin{tabular}{|c|c|c|}
\hline Gender & Frequency & Percent \\
\hline Male & 103 & 51.5 \\
\hline Female & 97 & 48.5 \\
\hline Total & 200 & 100.0 \\
\hline \multicolumn{3}{|l|}{ Age Range } \\
\hline Under 18 & 14 & 7.0 \\
\hline $18-25$ & 41 & 20.5 \\
\hline $26-35$ & 66 & 33.0 \\
\hline $36-45$ & 41 & 20.5 \\
\hline $46-55$ & 23 & 11.5 \\
\hline More than 55 & 15 & 7.5 \\
\hline Total & 200 & 100.0 \\
\hline \multicolumn{3}{|l|}{ Educational Level } \\
\hline Under Diploma & 7 & 3.5 \\
\hline Diploma & 27 & 13.5 \\
\hline Associate of Art & 27 & 13.5 \\
\hline B.S. /B.A. & 70 & 35.0 \\
\hline M.S. /M.A. & 41 & 20.5 \\
\hline $\mathrm{PhD}$ or Higher Degree & 28 & 14.0 \\
\hline \multicolumn{3}{|l|}{ Total } \\
\hline \multicolumn{3}{|l|}{ Occupation } \\
\hline Professor/ Teacher & 26 & 13.0 \\
\hline Physician/ Nurse/ Health Sec. & 13 & 6.5 \\
\hline Engineer/ Technician/ Technical Sec. & 30 & 15.0 \\
\hline Public/ Private Sec. Manager & 8 & 4.0 \\
\hline Financial/ Banking/ Accounting Sec. & 14 & 7.0 \\
\hline Consultant & 5 & 2.5 \\
\hline Scientific/ Research Sec. & 8 & 4.0 \\
\hline Art/ Architecture & 11 & 5.5 \\
\hline Sport Sec. & 6 & 3.0 \\
\hline Sales/ Marketing Sec. & 15 & 7.5 \\
\hline Producer/ Manufacturer & 8 & 4.0 \\
\hline Service Sec. & 12 & 6.0 \\
\hline Student & 22 & 11.0 \\
\hline Retired/ Unemployed & 9 & 4.5 \\
\hline Others & 13 & 6.5 \\
\hline Total & 200 & 100.0 \\
\hline \multicolumn{3}{|l|}{ Mobile Telecom Operators } \\
\hline Hamrah-e Avval & 126 & 63.0 \\
\hline Irancell & 54 & 27.0 \\
\hline Taliya & 20 & 10.0 \\
\hline \multicolumn{3}{|r|}{100.0} \\
\hline \multicolumn{3}{|l|}{ Other Operators } \\
\hline TKC & $\begin{array}{l}6 \\
194\end{array}$ & 3.0 \\
\hline \multirow{2}{*}{\multicolumn{3}{|c|}{$\begin{array}{l}\text { Total } \\
\text { Type of SIM }\end{array}$}} \\
\hline & & \\
\hline Post paid & 128 & 64.0 \\
\hline Prepaid & 72 & 36.0 \\
\hline Total & 200 & 100.0 \\
\hline
\end{tabular}


Table 3. Internal Consistency of factors with Cronbach's $\alpha$

\begin{tabular}{|l|c|}
\hline Factors & Cronbach's $\alpha$ \\
\hline Loyalty & 0.800 \\
Retention & 0.844 \\
eCRM & 0.842 \\
\hline
\end{tabular}

Table 4. Internal Consistency of Customer Retention Factors with Cronbach's $\alpha$

\begin{tabular}{|l|c|}
\hline Factors of Retention & Cronbach's $\alpha$ \\
\hline Customer Satisfaction & 0.602 \\
Customer Involvement & 0.757 \\
Trust & 0.656 \\
Attraction of Alternatives & 0.450 \\
Service Quality & 0.718 \\
Price & 0.755 \\
Switching Barrier & 0.776 \\
\hline
\end{tabular}

Table 5. Model Summary for Customer Loyalty

\begin{tabular}{|l|c|c|c|c|}
\hline Model & R & R Square & Adjusted R Square & Std. Error of the Estimate \\
\hline 1 & $0.663^{\mathrm{a}}$ & 0.439 & 0.436 & 0.93535 \\
2 & $0.707^{\mathrm{b}}$ & 0.500 & 0.495 & 0.88554 \\
\hline
\end{tabular}

Table 6. ANOVA ${ }^{\mathrm{c}}$

\begin{tabular}{|l|l|l|l|l|c|c|}
\hline Model & & Sum of Squares & Df & Mean Square & F & Sig. \\
\hline 1 & Regression & 135.530 & 1 & 135.530 & 154.913 & $0.000^{\mathrm{a}}$ \\
& Residual & 173.225 & 198 & 0.875 & & \\
& Total & 308.755 & 199 & & & \\
& Regression & 154.270 & 2 & 77.135 & 98.363 & $0.000^{\mathrm{b}}$ \\
& Residual & 154.485 & 197 & 0.784 & & \\
& Total & 308.755 & 199 & & & \\
\hline
\end{tabular}

Table 7. Coefficients ${ }^{\mathrm{a}}$

\begin{tabular}{|c|c|c|c|c|c|c|}
\hline \multicolumn{2}{|c|}{ Model } & \multicolumn{2}{|c|}{ Unstandardized Coefficients } & \multirow{2}{*}{$\begin{array}{l}\text { Standardized } \\
\text { Coefficients } \\
\text { Beta }\end{array}$} & \multirow[b]{2}{*}{$\mathrm{t}$} & \multirow[b]{2}{*}{ Sig. } \\
\hline & & $\mathrm{B}$ & Std. Error & & & \\
\hline \multirow[t]{2}{*}{1} & (Constant) & 1.883 & 0.180 & & 10.472 & 0.000 \\
\hline & Tangibility & 0.540 & 0.043 & 0.663 & 11.446 & 0.000 \\
\hline \multirow[t]{3}{*}{2} & (Constant) & 1.116 & 2 & & 4.819 & 0.000 \\
\hline & Tangibility & 0.508 & 197 & 0.623 & 12.204 & 0.000 \\
\hline & Scalability and Flexibility & 0.226 & 199 & 0.250 & 4.889 & 0.000 \\
\hline
\end{tabular}

a. Dependent Variable: Evaluation of Customer Loyalty 
Table 8. Model Summary for Customer Retention

\begin{tabular}{|l|c|c|c|c|}
\hline Model & R & R Square & Adjusted R Square & Std. Error of the Estimate \\
\hline 1 & $0.607^{\mathrm{a}}$ & 0.369 & 0.366 & 1.11897 \\
2 & $0.646^{\mathrm{b}}$ & 0.417 & 0.411 & 1.07842 \\
3 & $0.668^{\mathrm{c}}$ & 0.447 & 0.438 & 1.05320 \\
4 & $0.679^{\mathrm{d}}$ & 0.461 & 0.450 & 1.04156 \\
5 & $0.692^{\mathrm{e}}$ & 0.479 & 0.466 & 1.02692 \\
\hline
\end{tabular}

Table 9. ANOVA ${ }^{\mathrm{f}}$

\begin{tabular}{|l|llllll|}
\hline Model & & Sum of Squares & Df & Mean Square & F & Sig. \\
\hline 1 & Regression & 144.878 & 1 & 144.878 & 115.708 & $0.000^{\text {a }}$ \\
& Residual & 247.917 & 198 & 1.252 & & \\
& Total & 392.795 & 199 & & & \\
& Regression & 163.688 & 2 & 81.844 & 70.374 & $0.000^{\text {b }}$ \\
& Residual & 229.107 & 197 & 1.163 & & \\
& Total & 392.795 & 199 & & & $0.000^{\text {c }}$ \\
& Regression & 175.387 & 3 & 58.462 & 52.705 & \\
& Residual & 217.408 & 196 & 1.109 & & $0.000^{\text {d }}$ \\
& Total & 392.795 & 199 & & 41.769 & \\
& Regression & 181.250 & 4 & 45.312 & & $0.000^{\text {e }}$ \\
& Residual & 211.545 & 195 & 1.085 & & \\
& Total & 392.795 & 199 & & 35.694 & \\
& Regression & 188.208 & 5 & 37.642 & & \\
& Residual & 204.587 & 194 & 1.055 & & \\
& Total & 392.795 & 199 & & & \\
\hline
\end{tabular}
a. Predictors: (Constant), Personal Compatibility
b. Predictors: (Constant), Personal Compatibility, Professional Competence
c. Predictors: (Constant), Personal Compatibility, Professional Competence, Frontline Employees' Help
d. Predictors: (Constant), Personal Compatibility, Professional Competence, Frontline Employees' Help, Quality of Service
e. Predictors: (Constant), Personal Compatibility, Professional Competence, Frontline Employees' Help, Quality of Service, Pricing Policies Attraction
f. Dependent Variable: Evaluation of Customer Retention 


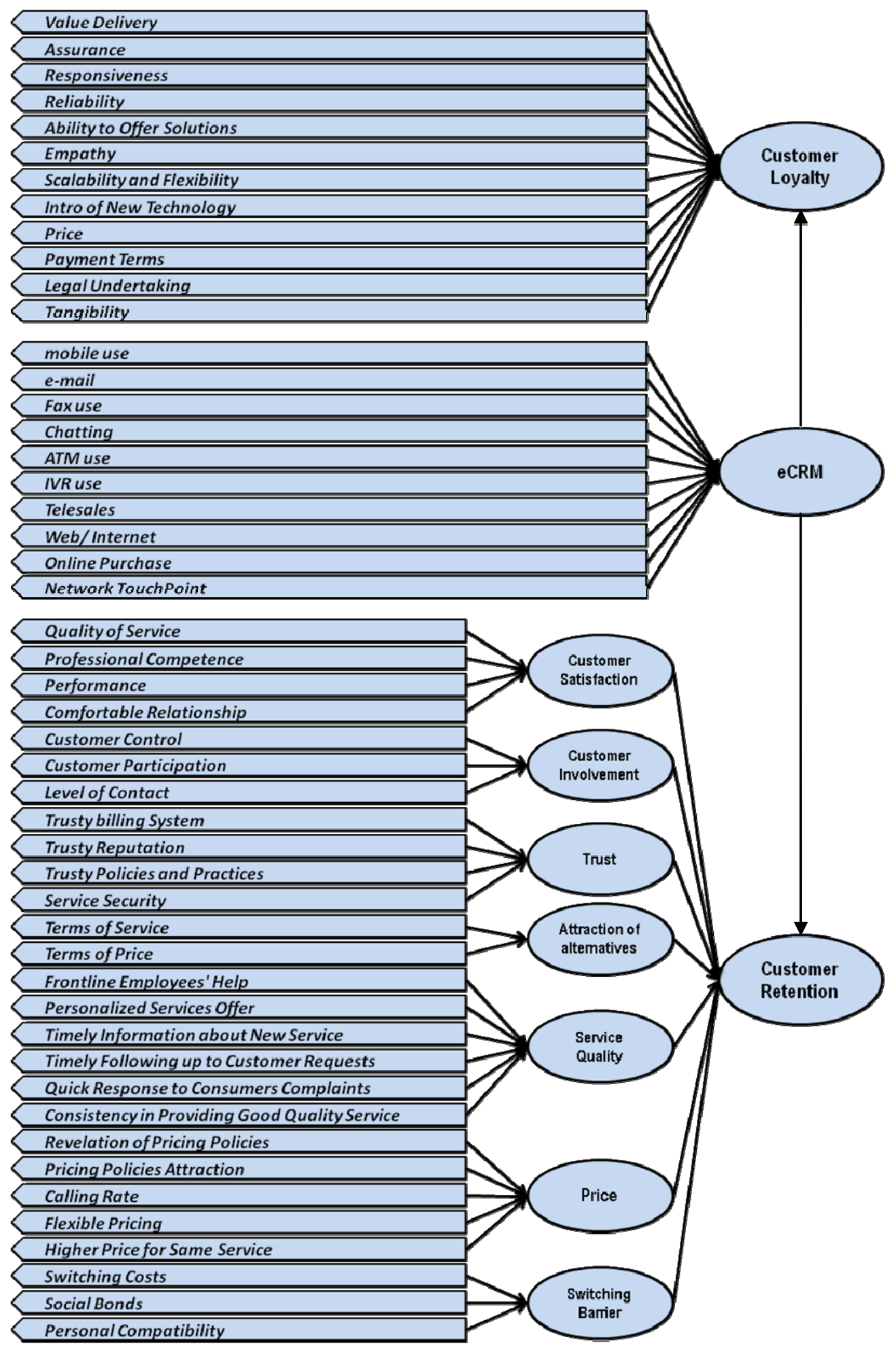

Figure 1. Model of this research 